Article

\title{
Synthesis of Industrially Useful Phenolic Compounds Esters by Means of Biocatalysts Obtained Along with Waste Fish Oil Utilization
}

\author{
Bartłomiej Zieniuk ${ }^{1, *(D)}$, Małgorzata Wołoszynowska ${ }^{2}$, Ewa Białecka-Florjańczyk ${ }^{1}$ \\ and Agata Fabiszewska ${ }^{1}$ (D) \\ 1 Department of Chemistry, Institute of Food Sciences, Warsaw University of Life Sciences, \\ 159c owoursynowska St., 02-776 Warsaw, Poland; ewa_bialecka_florjanczyk@sggw.edu.pl (E.B.-F.); \\ agata_fabiszewska@sggw.edu.pl (A.F.) \\ 2 Analytical Department, Łukasiewicz Research Network-Institute of Industrial Organic Chemistry, \\ 6 Annopol St., 03-236 Warsaw, Poland; woloszynowska@ipo.waw.pl \\ * Correspondence: bartlomiej_zieniuk@sggw.edu.pl; Tel.: +48-22-59-37-621
}

Received: 1 July 2020; Accepted: 17 July 2020; Published: 19 July 2020

\begin{abstract}
The purpose of the study was to utilize the waste fish oil after fish smoking process in $Y$. lipolytica yeast batch cultures in order to assess its valorization to whole-cell biocatalysts with lipolytic properties. Almost $90 \%$ of the waste carbon source in medium was used and batch cultures of Y. lipolytica W29 were characterized with biomass yield of $18.59 \mathrm{~g} / \mathrm{dm}^{3}$ and lipolytic activity of $53.41 \mathrm{U} / \mathrm{g}$. The yeast biomass was used as a whole-cell biocatalyst in the synthesis of esters of selected phenolic compounds (acetates of 2-phenylethanol, tyrosol (2-(4-hydroxyphenyl) ethanol) and 3-phenyl-1-propanol, and ethyl esters of phenylacetic, 4-hydroxyphenylacetic, 3-phenylpropanoic, and 3-(4-hydroxyphenyl) propanoic acids). Y. lipolytica biomass was able to catalyze esterification of 3-phenylpropanoic acid (conversion of 95\% after $24 \mathrm{~h}$ ), but conversion of other acids to their esters was very weak, and in the case of transesterification of aromatic alcohols with vinyl acetate, conversions were $27-63 \%$ after $24 \mathrm{~h}$. Synthesized esters were tested prior potential activities as food additives. Esters of hydroxylated phenolic compounds showed activity of $2.5 \mathrm{mg} / \mathrm{mL}$ against Klebsiella pneumoniae and Citrobacter freundii, exhibited similar antioxidant properties to their precursors, and were better soluble in lipids, which increases the possibility of their use in the food industry.
\end{abstract}

Keywords: lipases; phenolic compounds esters; waste fish oil; whole-cell catalysis; Yarrowia lipolytica

\section{Introduction}

Fish meat is a valuable food product, being a source of long-chain polyunsaturated fatty acids, as well as proteins rich in essential amino acids and also vitamins A, D, and E. The content of these chemical compounds is varied and depends on different factors, such as the species of fish, its age, or the type of food consumed [1,2]. On the other hand, industry development, including the food industry, is associated with the increase in post-production wastes and problems related to their utilization. Wastes from fish processing plants are mainly fish heads, bones, tails, and viscera. During fish processing, about $50 \%-75 \%$ of the total fish used becomes waste [3]. Fish waste can be used in the production of proteins hydrolysates, fodders, fishmeals, and silages, which can be then successfully used in animal production [4-6]. Furthermore, fish waste, like other agri-food industry waste, can be used to produce biogas and biodiesel (fatty acid alkyl esters) $[7,8]$. The amount of oil contained in these wastes varies between $40 \%$ and $65 \%$ [3]. Utilization of lipids in sewage farms is difficult, mainly due to their hydrophobicity. Fats favor the growth of Actinobacteria, which negatively affect the process of wastewater treatment, creating a floating sludge. Moreover, fats and oils that left the sewage plant after 
an incomplete wastewater treatment process can form a thin layer on the surface of water reservoirs, leading to a reduction in gas exchange, and after getting into the soil fats can block the pores and reduce microflora activity [9].

For these reasons, new unconventional methods are being sought, and traditional technologies are being modified in order to develop and valorize lipid waste from fish processing plants. Many publications reported the use of this waste in the production of enzymes, microbial oil, and polyunsaturated fatty acid concentrates [10-14]. One example is Yarrowia lipolytica-a very promising yeast species that is able to grow in media containing hydrophobic carbon sources, such as hydrocarbons, fatty acids, and triacylglycerols, as well as in waste cooking oils or waste motor oil $[15,16]$, with simultaneous ability to synthesize a wide group of metabolites, especially hydrolytic enzymes such as lipases, proteases, phosphatases, or RNases. Apart from enzymes, Y. lipolytica synthesizes also organic acids, erythritol, and $\gamma$-decalactone [17]. Lipases of microbial origin are widely used in food technology and these produced by Y. lipolytica become a subject of interest to many researchers. There are two fractions of Y. lipolytica lipases: extracellular (secreted to culture medium) and intracellular (found in cytosol or bounded to the cell wall structure), and these enzymes are coded by LIP genes family of which the major extracellular lipase is Lip2p, encoded by LIP2 gene [18]. Lipases, due to their ability to perform reactions in aqueous as well as in organic environments, can be used for various chemical processes, e.g., synthesis of enantiomerically pure compounds, biodiesel, or esters, both flavors, fragrances, and also with biological activity [19-21].

Phenolic compounds are secondary plant metabolites belonging to the polyphenol class. Great interest in this group of compounds is associated mainly with their antioxidant and antimicrobial activities. Additionally, phenolic compounds exert anti-proliferative, anti-inflammatory, and several other properties [22,23], and their derivatives are being presently tested in clinical trials for the treatment of acute ischemic stroke (ozagrel-imidazole-substituted cinnamic acid), convulsions (cinromide-trans-3-bromo- $N$-ethylcinnamamide), or different types of cancers (piplartine-an alkaloid found in the roots of Piper tuberculatum) [24]. The primary methods of phenolic acids modifications are the esterification of the carboxyl group with aliphatic alcohols, or with polyphenols glycosides or lipids modification via incorporation of phenolic acids [21,25]. Different esters of gallic acid, such as propyl (E310), octyl (E311), and dodecyl (E312) esters, are used as food additives with antioxidant role. Furthermore, esters of $p$-hydroxybenzoic acid, known as parabens, act as food preservatives, e.g., methyl or ethyl parabens, E214 and E218, respectively [26]. In many cases, the esterification of phenolic acids improves their properties-in this way, many functional and antioxidative properties are improved, and in the case of phenolic lipids, the oxidative stability and nutritional value of edible oils are increased, and also these compounds possessing ultraviolet adsorbing activity are valuable in the cosmetics industry $[21,25]$.

The aim of the work was to obtain Yarrowia lipolytica biomass with high lipolytic activity in medium containing waste oil after the fish smoking process and the use of the obtained biomass as a whole-cell biocatalyst in the synthesis of seven esters: acetates of 2-phenylethanol, tyrosol (2-(4-hydroxyphenyl) ethanol), and 3-phenyl-1-propanol, and ethyl esters of phenylacetic, 4-hydroxyphenylacetic, 3-phenylpropanoic, and 3-(4-hydroxyphenyl)propanoic acids. Moreover, antioxidant and antimicrobial properties of synthesized compounds were also investigated.

\section{Materials and Methods}

\subsection{Microorganisms}

The study was carried out using four Y. lipolytica strains: Y. lipolytica KKP 379 from the Collection of Industrial Microorganisms of Institute of Agricultural and Food Biotechnology in Warsaw (Poland), Y. lipolytica W29 (ATCC ${ }^{\circledR} 20460^{\mathrm{TM}}$ ) from GPMA Laboratory at the University of Burgundy (Dijon, France), and Y. lipolytica ATCC ${ }^{\circledR} 18942^{\mathrm{TM}}$ and Y. lipolytica ATCC ${ }^{\circledR} 90812^{\mathrm{TM}}$ (JM23) from American Type Culture Collection (ATCC, Manassas, VA, USA). Moreover, the following microorganisms were used 
in this study: Bacillus cereus PCM 482, B. subtilis PCM 486, Citrobacter freundii PCM 1492, Enterobacter cloacae PCM 2848, Enterococcus faecalis PCM 2909, Escherichia coli PCM 2057, Klebsiella pneumoniae PCM 1, Listeria monocytogenes PCM 2191, Proteus mirabilis PCM 543, Pseudomonas aeruginosa PCM 2058, Serratia marcescens PCM 549, and Staphylococcus aureus PCM 2054 purchased from the Polish Collection of Microorganisms (PCM) of Institute of Immunology and Experimental Therapy Polish Academy of Sciences (Wrocław, Poland); Candida cylindracea DSM-2031 from Leibniz Institute DSMZ-German Collection of Microorganisms and Cell Cultures (Braunschweig, Germany); and Saccharomyces cerevisiae and Rhodotorula mucilaginosa were isolated and identified in the Department of Chemistry (WULS, Poland). Furthermore, Candida antarctica Lipase B (CALB), which was purchased from Sigma-Aldrich (Poznan, Poland), was also used in the current study.

\subsection{Materials}

Waste fish oil from the fish processing plant located at the Podlaskie Voivodeship (Poland) was used as a carbon source in culture media. The other culture media components were purchased from BTL Sp. z o. o. (Łódź, Poland). Chemicals were purchased from Avantor Performance Materials Poland S.A. (Gliwice, Poland) and Sigma-Aldrich, and $p$-nitrophenyl laurate was synthesized in the Department of Chemistry [27].

\subsection{Yeast Cultures, Biomass Yield, and Lipolytic Activity Measurements}

Inoculum cultures of four Y. lipolytica strains were carried out in flat-bottom flasks in $100 \mathrm{~cm}^{3}$ of YPG medium (1\% yeast extract, $2 \%$ peptone, $2 \%$ glucose, $\mathrm{pH}=5$ ) for $24 \mathrm{~h}$ at $28^{\circ} \mathrm{C}$ on a rotary shaker.

Experimental cultures were carried out in YPF medium, where glucose was replaced with waste fish oil. The cultures lasted $72 \mathrm{~h}$. At 24-h intervals, dry biomass yield was analyzed using moisture analyzer (Radwag MAC 50/NH, Radwag, Poland) and lipolytic activity of biomass was also determined (after 48 and $72 \mathrm{~h}$ of cultures) by spectrophotometric measurement based on the hydrolysis of $p$-nitrophenyl laurate [28]. Briefly, yeast culture was centrifuged, then washed with $0.9 \%$ saline solution and $1 \mathrm{~g}$ of yeast biomass was suspended in $15 \mathrm{~mL}$ of distilled water and added to $0.3 \mathrm{mmol}$ of $p$-nitrophenyl laurate dissolved in $2 \mathrm{~mL}$ of heptane. Hydrolysis reaction was performed on a magnetic stirrer at $37^{\circ} \mathrm{C}$, and after $15 \mathrm{~min}$, an absorbance was measured at $410 \mathrm{~nm}$ in UV/Vis spectrophotometer. Results were expressed as Units of activity (the enzyme quantity that liberated $1 \mu \mathrm{mol}$ of $p$-nitrophenol per minute under the assay conditions at $37^{\circ} \mathrm{C}$ ) per gram of biomass.

The strain characterized by the highest biomass yield and the highest lipolytic activity was selected for batch cultivation in a BIOFLO 3000 laboratory bioreactor (New Brunswick Scientific, Edison, NJ, USA) with a working capacity of $4 \mathrm{dm}^{3}$ in YPF medium and $0.0375 \%(v / v)$ inoculum at $28^{\circ} \mathrm{C}, 350 \mathrm{rpm}$ and aeration with compressed air at a flow of $105 \mathrm{dm}^{3} / \mathrm{h}$ per $1 \mathrm{dm}^{3}$ of medium for $42 \mathrm{~h}$. Similarly to flask cultures, biomass yield and lipolytic activity were measured. During bioreactor culture, an automatic measurement of the culture $\mathrm{pH}$ and oxygen consumption was carried out, the values of which allowed determining yeast growth phases. At the end of the culture, yeast biomass was separated from the supernatant by centrifugation in Sigma 4-15 (Sigma Laborzentrifugen GmbH, Osterode am Harz, Germany) at $8000 \mathrm{rpm}$ for $7 \mathrm{~min}$, washed with saline, and centrifuged again to remove residuals of culture medium and waste fish oil.

In the supernatant, the residual content of waste fish oil was also determined. Supernatant was concentrated with vacuum evaporator and 3-time extraction with n-hexane was carried out. Organic phases were collected, then the solvent was evaporated in Buchi Rotavapor R-200 (Buchi AG, Flawil, Switzerland) and the remaining oil from the culture was weighed.

\subsection{Esters Synthesis}

Syntheses of seven esters were carried out with raw yeast biomass $(5 \mathrm{~g})$ or CALB (addition of $5 \%$ by weight of substrates) as biocatalysts (Table 1). Ethyl esters were synthesized by reacting the appropriate acid (phenylacetic, 4-hydroxyphenylacetic, 3-phenylpropanoic, or 3-(4-hydroxyphenyl)propanoic acid; 
$0.0025 \mathrm{~mol})$ with ethanol $(0.005 \mathrm{~mol})$, and acetates as a result of transesterification of vinyl acetate $(0.0025 \mathrm{~mol})$ with 2-phenylethanol, tyrosol, or 3-phenyl-1-propanol $(0.0025 \mathrm{~mol})$. Reactions were carried out in flasks in $10 \mathrm{~mL}$ of isooctane at $37^{\circ} \mathrm{C}$.

Table 1. Lipase-catalyzed synthesis of phenolic compounds esters.

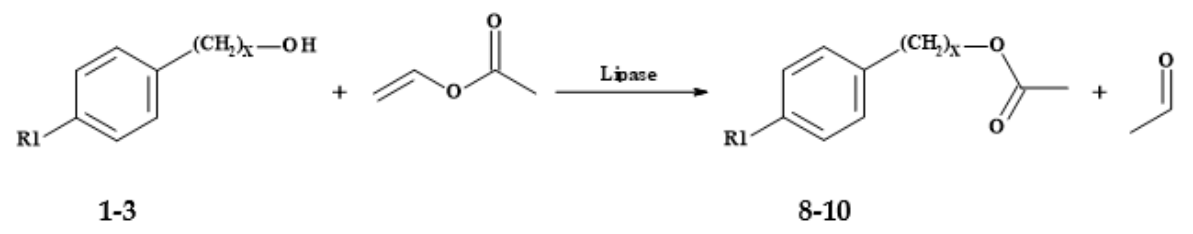<smiles>[M]c1ccc(CCC(=O)O)cc1</smiles>

4-7

11-14

\begin{tabular}{cccc}
\hline Compounds & Phenolic Compound Name/Derivative of & R1 & $\mathbf{X}$ \\
\hline 1,8 & 2-Phenylethanol & $-\mathrm{H}$ & 2 \\
2,9 & Tyrosol & $-\mathrm{OH}$ & 2 \\
3,10 & 3-Phenyl-1-propanol & $-\mathrm{H}$ & 3 \\
4,11 & Phenylacetic acid & $-\mathrm{H}$ & 1 \\
5,12 & 4-Hydroxyphenylacetic acid & $-\mathrm{OH}$ & 1 \\
6,13 & 3-Phenylpropanoic acid & $-\mathrm{H}$ & 2 \\
7,14 & 3-(4-Hydroxyphenyl)propanoic acid & $-\mathrm{OH}$ & 2 \\
\hline
\end{tabular}

\subsection{Gas Chromatography}

Samples were withdrawn from flasks after $4 \mathrm{~h}$ and $24 \mathrm{~h}$ of reactions, and then were derivatized with pyridine and BSTFA ( $\mathrm{N}, \mathrm{O}$-bis(trimethylsilyl)trifluoroacetamide) $+1 \%$ TMCS (trimethylchlorosilane) added in equal volumes and heated for $30 \mathrm{~min}$ at $70{ }^{\circ} \mathrm{C}$. Derivatized samples were analyzed by gas chromatography equipped with flame ionization detector (GC-FID) using Agilent Technologies 7820A with HP- 5 column $(0.25 \mathrm{~mm}, 30 \mathrm{~m}, 0.25 \mu \mathrm{m})$ (Agilent Technologies, Santa Clara, CA, USA). Nitrogen, at a flow rate of $1.5 \mathrm{~mL} / \mathrm{min}$, was used as carrier gas. The temperature program was as follows: $70^{\circ} \mathrm{C}$ for $3 \mathrm{~min}, 70{ }^{\circ} \mathrm{C}$ to $150{ }^{\circ} \mathrm{C}\left(3{ }^{\circ} \mathrm{C} / \mathrm{min}\right), 150{ }^{\circ} \mathrm{C}$ to $300^{\circ} \mathrm{C}\left(40{ }^{\circ} \mathrm{C} / \mathrm{min}\right)$, and $300{ }^{\circ} \mathrm{C}$ for $10 \mathrm{~min}$. Injector and detector temperatures were $250^{\circ} \mathrm{C}$ and $290^{\circ} \mathrm{C}$, respectively, and injection volume was $1 \mu \mathrm{L}$. Percentage conversion was calculated based on area under peaks of phenolic compound and its ester.

\subsection{Esters Purification}

After the reaction, the biomass was separated from the reactants by centrifugation, then the solvent was evaporated. Esters were purified using silica gel column chromatography with chloroform (for purification of 2-phenylethyl acetate, 3-phenyl-1-propyl acetate, and ethyl phenylacetate) or a mixture of heptane: ethyl acetate $(5: 2(v / v))$, for purification of other esters as eluents.

The structures of the synthesized compounds were confirmed using ${ }^{1} \mathrm{H}$ NMR. Compounds spectra were recorded using a Bruker AVANCE $300 \mathrm{MHz}$ spectrometer (Bruker, Billerica, MA, USA) with $\mathrm{CDCl}_{3}$ as a solvent. Proton chemical shifts of obtained esters are reported below in ppm ( $\delta$ ) relative to tetramethylsilane (TMS), which was used as an internal standard. Raw NMR data (e.g., fid files) are available in the Supplementary Materials.

Phenethyl acetate (8) ${ }^{1} \mathrm{H}$ NMR: $\delta 2.07(3 \mathrm{H}, \mathrm{s}), 2.97(2 \mathrm{H}, \mathrm{t}, J=7.1 \mathrm{~Hz}), 4.32(2 \mathrm{H}, \mathrm{t}, J=7.1 \mathrm{~Hz})$, $7.30(5 \mathrm{H}, \mathrm{m})$

Tyrosyl acetate (9) ${ }^{1} \mathrm{H}$ NMR: $\delta 2.08(3 \mathrm{H}, \mathrm{s}), 2.89(2 \mathrm{H}, \mathrm{t}, J=7.1 \mathrm{~Hz}), 4.27(2 \mathrm{H}, \mathrm{t}, J=7.1 \mathrm{~Hz}), 5.54(1 \mathrm{H}, \mathrm{s})$, $6.80(2 \mathrm{H}, \mathrm{d}), 7.09(2 \mathrm{H}, \mathrm{d})$ 
3-Phenyl-1-propyl acetate (10) ${ }^{1} \mathrm{H}$ NMR: $\delta 1.99(2 \mathrm{H}, \mathrm{m}), 2.07(3 \mathrm{H}, \mathrm{s}), 2.66(2 \mathrm{H}, \mathrm{t}, J=7.1 \mathrm{~Hz})$, $4.26(2 \mathrm{H}, \mathrm{t}, J=7.1 \mathrm{~Hz}), 7.28(5 \mathrm{H}, \mathrm{m})$

Ethyl phenylacetate (11) ${ }^{1} \mathrm{H}$ NMR: $\delta 1.28(3 \mathrm{H}, \mathrm{t}, J=7.1 \mathrm{~Hz}), 3.65(2 \mathrm{H}, \mathrm{s}), 4.18(2 \mathrm{H}, \mathrm{q}, J=7.1 \mathrm{~Hz})$, $7.33(5 \mathrm{H}, \mathrm{m})$

Ethyl 4-hydroxyphenylacetate (12) ${ }^{1} \mathrm{H}$ NMR: $\delta 1.28(3 \mathrm{H}, \mathrm{t}, J=7.1 \mathrm{~Hz}), 3.57(2 \mathrm{H}, \mathrm{s}), 4.18(2 \mathrm{H}, \mathrm{q}$, $J=7.1 \mathrm{~Hz}), 5.90(1 \mathrm{H}, \mathrm{s}), 6.75(2 \mathrm{H}, \mathrm{d}), 7.13(2 \mathrm{H}, \mathrm{d})$

Ethyl 3-phenylpropanoate (13) ${ }^{1} \mathrm{H}$ NMR: $\delta 1.22(3 \mathrm{H}, \mathrm{t}, J=7.1 \mathrm{~Hz}), 2.60(2 \mathrm{H}, \mathrm{t}, J=7.1 \mathrm{~Hz}), 2.94(2 \mathrm{H}$, $\mathrm{t}, J=7.1 \mathrm{~Hz}), 4.11(2 \mathrm{H}, \mathrm{q}, J=7.1 \mathrm{~Hz}), 7.30(5 \mathrm{H}, \mathrm{m})$

Ethyl 3-(4-hydroxyphenyl)propanoate (14) ${ }^{1} \mathrm{H}$ NMR: $\delta 1.26(3 \mathrm{H}, \mathrm{t}, J=7.1 \mathrm{~Hz}), 2.61(2 \mathrm{H}, \mathrm{t}$, $J=7.1 \mathrm{~Hz}), 2.90(2 \mathrm{H}, \mathrm{t}, J=7.1 \mathrm{~Hz}), 4.15(2 \mathrm{H}, \mathrm{q}, J=7.1 \mathrm{~Hz}), 5.06(\mathrm{~s}, 1 \mathrm{H}), 6.71-6.82(2 \mathrm{H}, \mathrm{m}), 7.03-7.14$ $(2 \mathrm{H}, \mathrm{m})$.

\subsection{Evaluation of Antioxidant Activity}

The antioxidant activity of the synthesized esters was studied by the DPPH• radical method [29] and the CUPRAC (Cupric Reducing Antioxidant Capacity) method, which uses the reduction of $\mathrm{Cu}$ (II) to $\mathrm{Cu}(\mathrm{I})$ ions bound in a complex with neocuproine (2,9-dimethyl-1,10-phenanthroline) [30]. In the case of the DPPH• radical method, the $\mathrm{IC}_{50}$ parameter was calculated, i.e., the concentration of the compound that reduces $50 \%$ of the radicals. Trolox Equivalent Antioxidant Capacity (TEAC) was determined in the CUPRAC method.

\subsection{Evaluation of Antimicrobial Activity}

The minimum inhibitory concentration (MIC) of esters and their precursors was determined by the microdilution broth method according to ISO [31] and EUCAST [32] against 12 bacteria and 4 yeast species. Moreover, minimum microbicidal concentrations (MMC) were determined. Briefly, $3 \mu \mathrm{L}$ of microorganism culture from each well with no observed growth was transferred onto Mueller-Hinton Agar (BTL Sp. z o. o., Łódź, Poland) for bacteria or Sabouraud Agar (BTL Sp. z o. o., Łódź, Poland) for yeast. Subsequently, agar plates were incubated at $37^{\circ} \mathrm{C}$ for $24 \mathrm{~h}$ for bacteria or $28^{\circ} \mathrm{C}$ for $48 \mathrm{~h}$ for yeast.

\subsection{Calculation of Selected Properties of Tested Compounds}

Selected properties of the compounds were calculated with Osiris DataWarrior (DataWarrior V5.0.0, Idorsia Pharmaceuticals Ltd., Allschwil, Switzerland). The following properties were calculated: molecular weights, cLogP (partition coefficient, measure of lipophilicity), cLogS (logarithm of S, where $\mathrm{S}$ is water solubility in $\mathrm{mol} / \mathrm{L}, \mathrm{pH}=7.5,25^{\circ} \mathrm{C}$ ), number of hydrogen acceptors (H-Acceptors), hydrogen donors (H-Donors), other atoms (Non-H Atoms), electronegative atoms, $\mathrm{sp}^{3}$-Atoms, as well as Total Surface Area (TSA, sum of the surfaces of all atoms in molecule) and Topological Polar Surface Area (TPSA, sum of the surfaces of all polar atoms). Calculated properties were summarized in Table 2. 
Table 2. Calculated properties of tested compounds.

\begin{tabular}{|c|c|c|c|c|c|c|c|c|c|c|}
\hline & $\begin{array}{c}\text { Molecular } \\
\text { Weight } \\
\text { (g/mol) }\end{array}$ & $\operatorname{cLog} P$ & cLogS & H-Acceptors & H-Donors & $\begin{array}{l}\text { Non-H } \\
\text { Atoms }\end{array}$ & $\begin{array}{l}\text { Electronegative } \\
\text { Atoms }\end{array}$ & $\mathrm{sp}^{3}$-Atoms & $\begin{array}{c}\text { Total } \\
\text { Surface } \\
\text { Area }(\AA)\end{array}$ & $\begin{array}{c}\text { Topological } \\
\text { Polar Surface } \\
\text { Area (A) }\end{array}$ \\
\hline 2PE (1) & 122.17 & 1.49 & -1.61 & 1 & 1 & 9 & 1 & 3 & 107.13 & 20.23 \\
\hline PEA (8) & 164.20 & 1.98 & -2.02 & 2 & 0 & 12 & 2 & 4 & 140.79 & 26.30 \\
\hline $\mathrm{T}(2)$ & 138.17 & 1.15 & -1.32 & 2 & 2 & 10 & 2 & 4 & 113.48 & 40.46 \\
\hline TA (9) & 180.20 & 1.63 & -1.73 & 3 & 1 & 13 & 3 & 5 & 147.14 & 46.53 \\
\hline 3P1P (3) & 136.19 & 1.95 & -1.88 & 1 & 1 & 10 & 1 & 4 & 120.89 & 20.23 \\
\hline 3Р1PA (10) & 178.23 & 2.43 & -2.29 & 2 & 0 & 13 & 2 & 5 & 154.55 & 26.30 \\
\hline PA (4) & 136.15 & 1.14 & -1.59 & 2 & 1 & 10 & 2 & 2 & 111.12 & 37.30 \\
\hline EP (11) & 164.20 & 1.98 & -2.02 & 2 & 0 & 12 & 2 & 4 & 140.79 & 26.30 \\
\hline 4HPAA (5) & 152.15 & 0.80 & -1.30 & 3 & 2 & 11 & 3 & 3 & 117.47 & 57.53 \\
\hline E4HPA (12) & 180.20 & 1.63 & -1.73 & 3 & 1 & 13 & 3 & 5 & 147.14 & 46.53 \\
\hline 3РPA (6) & 150.18 & 1.60 & -1.86 & 2 & 1 & 11 & 2 & 3 & 124.88 & 37.30 \\
\hline E3PP (13) & 178.23 & 2.43 & -2.29 & 2 & 0 & 13 & 2 & 5 & 154.55 & 26.30 \\
\hline 4HPPA (7) & 166.18 & 1.25 & -1.57 & 3 & 2 & 12 & 3 & 4 & 131.23 & 57.53 \\
\hline E4HPP (14) & 194.23 & 2.09 & -2.00 & 3 & 1 & 14 & 3 & 6 & 160.90 & 46.53 \\
\hline
\end{tabular}

Abbreviations: 2PE—2-Phenylethanol; PEA—Phenethyl acetate; T—Tyrosol, TA—Tyrosyl acetate; 3P1P—3-Phenyl-1-propanol; 3P1PA—3-Phenyl-1-propyl acetate; PA—Phenylacetic acid; EP-Ethyl phenylacetate; 4HPAA-4-Hydroxyphenylacetic acid; E4HPA-Ethyl 4-hydroxyphenylacetate; 3PPA-3-Phenylpropanoic acid; E3PP-Ethyl 3-phenylpropanoate; 4HPPA-3-(4-hydroxyphenyl)propanoic acid; E4HPP-Ethyl 3-(4-hydroxyphenyl)propanoate. 


\subsection{Statistical Analysis}

Statistical analysis as well as cluster analysis were performed using Statistica 13.3 software (TIBCO Software Inc., Palo Alto, CA, USA). The results were analyzed using one-way analysis of variance (ANOVA) and Tukey's post-hoc test. The significance level was $\alpha=0.05$.

\section{Results and Discussion}

\subsection{Yeasts Cultivation and Biocatalyst Preparation}

In preliminary studies, four strains of $Y$. lipolytica were compared for growth and production of intracellular lipolytic enzymes in a medium containing waste fish oil as a main carbon source (Figure 1).

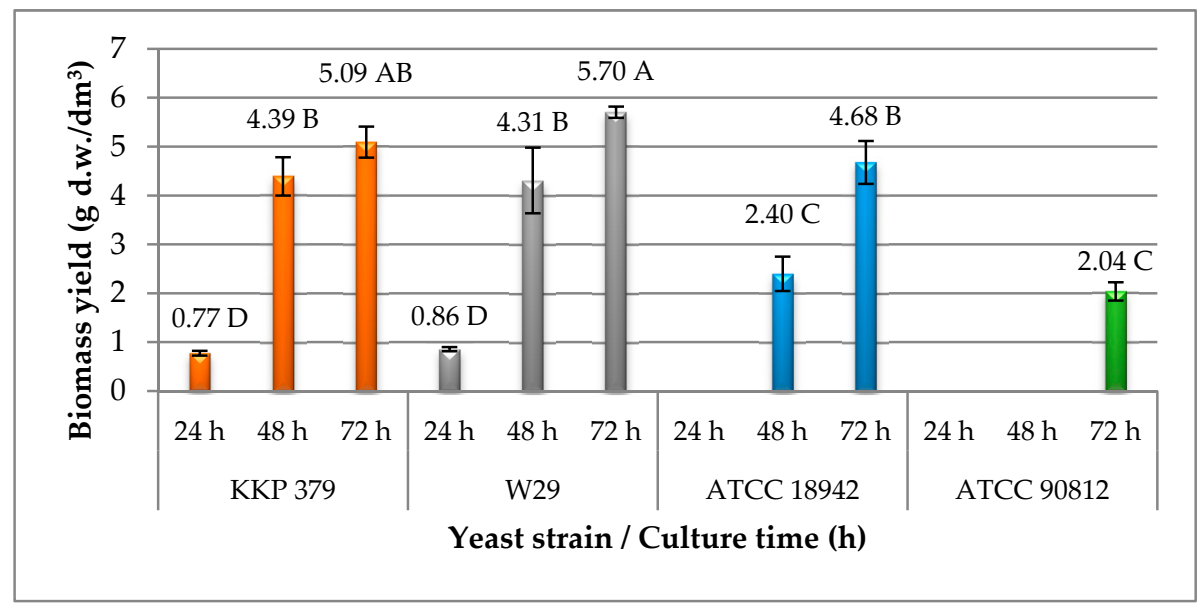

Figure 1. Biomass yield of four Y. lipolytica strains in 72-h culture in medium with waste fish oil. Means with the same letter did not differ significantly $(\alpha<0.05)$.

The highest dry biomass yield values were obtained in cultures of KKP 379 and W29 strains. These values after $72 \mathrm{~h}$ of culture were $5.09 \pm 0.32$ and $5.70 \pm 0.12 \mathrm{~g} \cdot \mathrm{d} . \mathrm{w} . / \mathrm{dm}^{3}$, respectively. For the remaining strains, their growth was definitely weaker and a biomass yield of $4.68 \pm 0.44 \mathrm{~g} \mathrm{~d} . \mathrm{w} . / \mathrm{dm}^{3}$ after $72 \mathrm{~h}$ was obtained for the ATCC 18942 strain. The weakest growth was observed in the ATCC 90812 strain culture, and its biomass yield after $72 \mathrm{~h}$ was more than two-fold lower in comparison with other tested strains and it was $2.04 \pm 0.19 \mathrm{~g}$ d.w. $/ \mathrm{dm}^{3}$.

At the same stage of the experiment, the lipolytic activity of biomass was also examined (Figure 2). Similarly to biomass yield values, KKP 379 and W29 strains were characterized by the highest intracellular lipolytic enzyme activity, which after $48 \mathrm{~h}$ of cultivation were $27.30 \pm 0.64$ and $24.51 \pm 1.28 \mathrm{U} / \mathrm{g}$, respectively. These values decreased after further $24 \mathrm{~h}$ of cultures and were $17.62 \pm 2.22 \mathrm{U} / \mathrm{g}$ for KKP 379 and $12.63 \pm 1.53 \mathrm{U} / \mathrm{g}$ for W29 strain. Lipolytic activities of ATCC 18942 and ATCC 90812 strains were very low and after $72 \mathrm{~h}$ they were $2.95 \pm 0.68$ and $0.52 \pm 0.07 \mathrm{U} / \mathrm{g}$, respectively. Measurement of lipolytic activity for these strains after $48 \mathrm{~h}$ was not possible due to the very weak growth in this medium.

The synthesis of lipolytic enzymes by Y. lipolytica depends on the phase of cell growth. According to Fabiszewska et al. [33], lipases of Y. lipolytica were the most active in the logarithmic phase of growth and in the culture of Y. lipolytica KKP 379 strain the highest activity was obtained after $24 \mathrm{~h}$ of culture, and then this value decreased and after $65 \mathrm{~h}$ remained stable. Lipases produced by Y. lipolytica are induced enzymes and their biosynthesis is stimulated by lipids and their derivatives used as a carbon sources in media [18]. Akpinar and Ucar [34] also conducted research on the production of lipolytic enzymes by various strains of $Y$. lipolytica in media containing fish oil. Similarly to the current research, the authors obtained different enzymatic activities for the tested strains, which proves that strains differ from each other in substrate specificity and fish oil differently induced enzymes production. 


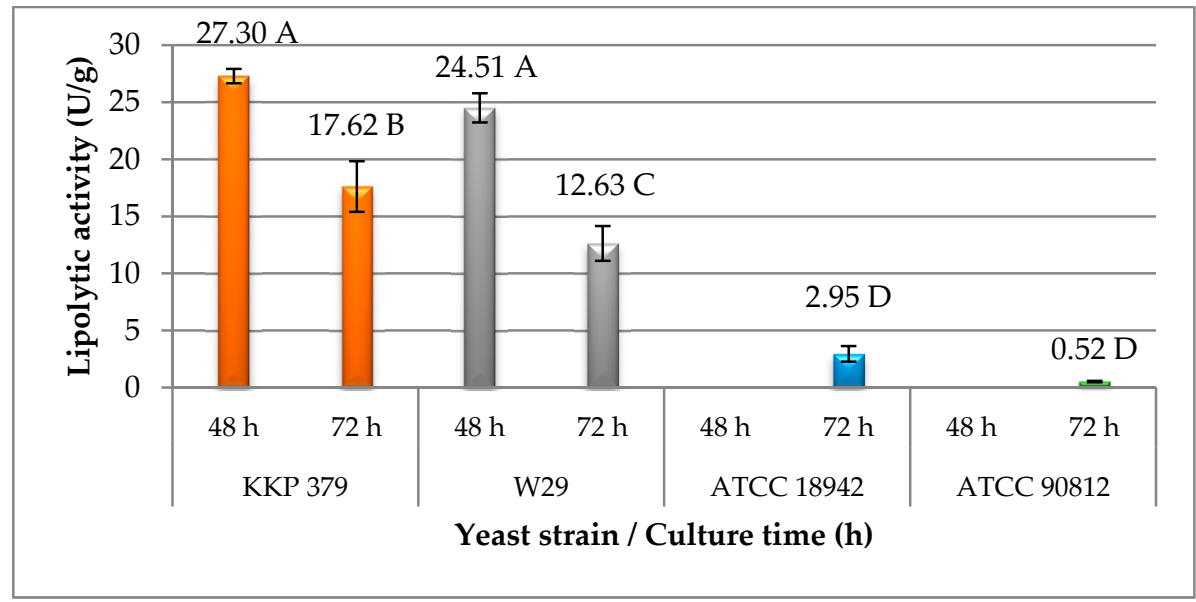

Figure 2. Lipolytic activity of biomass of four Y. lipolytica strains in 72-h culture in medium with waste fish oil. Means with the same letter did not differ significantly $(\alpha<0.05)$.

Y. lipolytica W29 was selected for the next stage of the research, i.e., cultivation in a laboratory bioreactor. During the 2-day batch culture in the laboratory bioreactor, the $\mathrm{pH}$ value did not change much and varied between 4.5 and 5.5 (Figure 3).

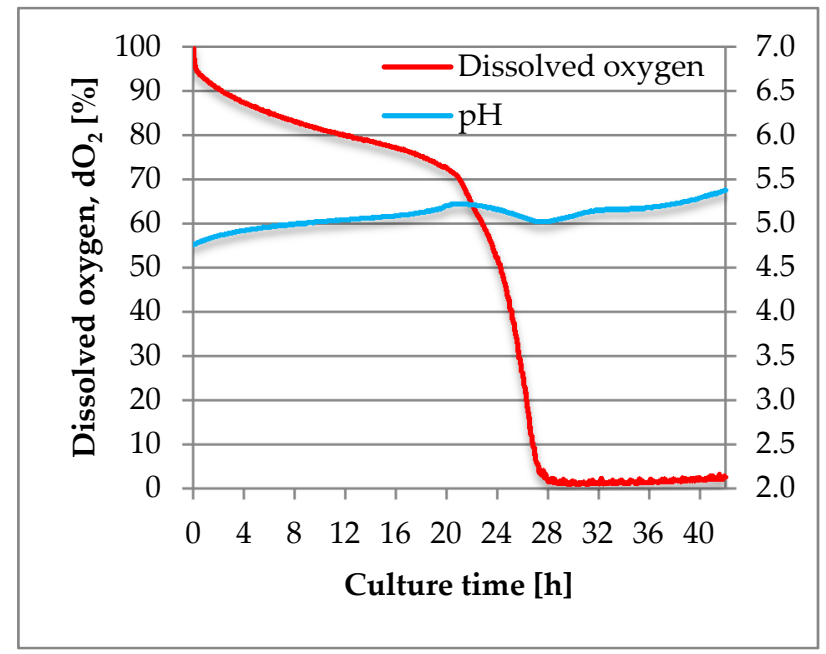

Figure 3. Changes in the level of dissolved oxygen and $\mathrm{pH}$ in stationary culture of Y. lipolytica W29 in medium with waste fish oil.

Yeast began to multiply intensively after $24 \mathrm{~h}$ of cultivation, which can be seen by a sudden change in the value of dissolved oxygen and it corresponds to the logarithmic phase of yeast growth. At the end of the cultivation, the biomass yield was $18.59 \pm 0.32 \mathrm{~g} \mathrm{~d} . \mathrm{w} . / \mathrm{dm}^{3}$ and the lipolytic activity of the biomass was $53.41 \pm 0.81 \mathrm{U} / \mathrm{g}$ (Table 3), which means that, compared to flask cultures, these values were over three-fold higher for biomass yield and two-fold higher for lipolytic activity.

Table 3. Selected parameters characterizing the culture of Y. lipolytica W29 in the laboratory bioreactor in the medium with waste fish oil.

\begin{tabular}{cccc}
\hline Culture Time (h) & $\begin{array}{c}\text { Biomass Yield } \\
\text { (g d.w./dm }{ }^{\mathbf{3}} \text { ) }\end{array}$ & Lipolytic Activity (U/g) & $\begin{array}{c}\text { Residual Oil in } \\
\text { Supernatant (g/dm }{ }^{3} \text { ) }\end{array}$ \\
\hline 42 & $18.59 \pm 0.32$ & $53.41 \pm 0.81$ & $2.14 \pm 0.11$ \\
\hline
\end{tabular}


Yeasts from Y. lipolytica species are extremely aerobic. The reduced oxygen content inhibits cell growth of this species, therefore high oxygenation and mixing in bioreactor cultures are used and possibility of using compressed air aeration allows to increase the production of metabolites [35]. It is also worth mentioning that the remaining concentration of waste fish oil in the medium was $2.14 \pm 0.11 \mathrm{~g} / \mathrm{dm}^{3}$ at an initial concentration of $20 \mathrm{~g} / \mathrm{dm}^{3}$, therefore nearly $90 \%$ of the carbon source was used by the yeast for growth, energy processes, and metabolites production. Yeast biomass was separated from supernatant by centrifugation after 42-h culture and frozen prior to using in the next stage of experiment.

\subsection{Biomass-Catalyzed Ester Synthesis}

In the next stage of work, seven esters syntheses were performed (Table 1) with two different biocatalysts-C. antarctica lipase B (CALB) and Y. lipolytica W29 biomass obtained in previous stage of experiment. Table 4 shows percentage conversion of phenolic compounds to its ethyl or acetate esters in reactions catalyzed by aforementioned biocatalysts.

Table 4. Percentage conversion of phenolic compounds to its ethyl or acetate esters after $4 \mathrm{~h}$ and $24 \mathrm{~h}$ (in brackets) of reaction with Y. lipolytica biomass or Candida antarctica lipase B as catalysts.

\begin{tabular}{|c|c|c|}
\hline \multirow{3}{*}{ Compound } & \multicolumn{2}{|c|}{ Catalyst } \\
\hline & Y. lipolytica Biomass & Candida antarctica Lipase B \\
\hline & \multicolumn{2}{|c|}{ Conversion $(\%)$} \\
\hline Phenethyl acetate (8) & $32(48)$ & $87(90)$ \\
\hline Tyrosyl acetate (9) & $5(27)$ & $\mathrm{T}^{*}$ \\
\hline 3-Phenyl-1-propyl acetate (10) & $28(63)$ & $78(90)$ \\
\hline Ethyl phenylacetate (11) & $\mathrm{T}$ & $68(90)$ \\
\hline Ethyl 4-hydroxyphenylacetate (12) & $\mathrm{T}$ & $56(60)$ \\
\hline Ethyl 3-phenylpropanoate (13) & $94(95)$ & $97(98)$ \\
\hline Ethyl 3-(4-hydroxyphenyl)propanoate (14) & $4(4)$ & $\mathrm{T}$ \\
\hline
\end{tabular}

* T-traces.

Only in the case of esterification of 3-phenylpropanoic acid were the obtained results comparable, and after $4 \mathrm{~h}$ of reactions more than $90 \%$ of substrate was esterified.

Enzymatic synthesis of ethyl 3-(4-hydroxyphenyl)propanoate proceeded unsuccessfully using both catalysts and maximum of $4 \%$ of conversion was obtained with Y. lipolytica biomass. Similarly, in the transesterification of tyrosol, only trace amounts of ester (below $2 \%$ ) were obtained in case of CALB. In regard to whole-cell transesterification of tyrosol, slightly better results were obtained after $4 \mathrm{~h}$ ( $5 \%$ of conversion), and after $24 \mathrm{~h}$ almost $30 \%$ of conversion has been achieved. Such a poor results may come from low solubility of the substrate in organic reaction medium. It is known that the substrate solubility plays an important role in lipase-catalyzed reactions, resulting in the selection of a suitable solvent [27]. Moreover, organic solvents affect activity and stability of enzyme used. For a more accurate comparison of the catalytic properties of $Y$. lipolytica biomass and CALB, isooctane was chosen as the solvent in conducted reactions. It resulted in decreased solubility of substrates with hydroxyl group bounded to the aromatic ring. Wang et al. [36] applied synthesis of benzyl cinnamate through lipase-catalyzed esterification in acetone, chloroform, toluene, and isooctane as reaction medium. In their study, Lipozyme TLIM (lipase from Thermomyces lanuginosus) showed the highest yield in isooctane while Novozym 435 (CALB) exhibited the best performance in toluene [36]. In CALB-catalyzed esterification of cinnamic acid with butanol, Jakovetić et al. [37] tested six different organic solvents (tert-butanol, $n$-butanol, chloroform, hexane, isooctane, and hexadecane). The yield of ester ranged from $9 \%$ to $45 \%$ (lowest yield in reaction with chloroform and the highest with isooctane). For hydrocarbons, the yield was from $16 \%$ to $19 \%$ and for isomers of butanol- $21 \%$ for $n$-butanol and $28 \%$ for tert-butanol [37].

With regard to phenethyl and 3-phenyl-1-propyl, acetate synthesis conversions with CALB were higher $(90 \%$ after $24 \mathrm{~h}$ ), and Y. lipolytica biomass was able to convert $48 \%$ and $63 \%$ of substrates to its 
esters, respectively. The acetaldehyde formed during the transesterification reactions could affect the enzyme's activity. Weber et al. [38] tested sensitivity of 26 microbial lipases towards acetaldehyde, and lipases from Candida rugosa and Geotrichum candidum were especially susceptible to acetaldehyde. The same authors suggested that lysine content can be particularly responsible for acetaldehyde sensitivity, and aforementioned lipases have highly accessible lysine residues (Lys75, involved in lid fixing in enzyme open conformation), thus these lipases are prone to deactivation [39]. To overcome this problem, Weber and Faber [40] proposed two methods of stabilization of lipases-covalent immobilization of lipase using epoxy-activated carrier or adsorption onto Celite 545.

The largest differences in conversion are noticeable in the esterification of phenylacetic and 4-hydroxyphenylacetic acid. When using Y. lipolytica biomass, there were hardly any esterification products after $24 \mathrm{~h}$ of reaction. The conversions were significantly higher in the CALB-catalyzed reactions-68\% after $4 \mathrm{~h}$ and $90 \%$ after $24 \mathrm{~h}$ in esterification of phenylacetic acid. For 4-hydroxyphenylacetic acid, the reaction equilibrium was established after $4 \mathrm{~h}$ of reaction and hardly changed after $24 \mathrm{~h}$ and was about $60 \%$. Guyot et al. [41] claimed that ester yields depend on the electron distribution of substrates, which is closely related to reactivity of the carboxylic group. Moreover, carbon chain length of both alcohol and that between aromatic ring and carboxylic function in phenolic acids affects the reactivity [41]. Reviewing the results obtained in esterification of phenolic acids with Y. lipolytica biomass as a catalyst, it can be seen that the aliphatic carbon chain length was crucial for the reaction yield of the synthesized ethyl esters. Preferably, the aliphatic carbon chain must contain at least two methylene units as in the case of 3-phenylpropanoic acid (95\% conversion) in comparison with one unit in phenylacetic acid (only traces of the product).

\subsection{Evaluation of Antioxidant Activity of Obtained Esters and Their Precursors}

The next step after synthesis, purification, and confirmation of esters structures was the analysis of their biological properties, i.e., antioxidant and antimicrobial activity. Table 5 shows the $\mathrm{IC}_{50}$ values, i.e., the concentration that causes $50 \%$ reduction of DPPH• radicals calculated in two units: milligrams per milliliter and molar concentration, as well as TEAC values (Trolox Equivalent Antioxidant Capacity) measured by means of CUPRAC method.

Table 5. Comparison of antioxidant activity of tested compounds by methods with DPPH• radical and CUPRAC.

\begin{tabular}{|c|c|c|c|}
\hline \multirow{3}{*}{ Compound } & \multicolumn{3}{|c|}{ Antioxidant Activity } \\
\hline & \multicolumn{2}{|c|}{ DPPH• } & \multirow{2}{*}{$\begin{array}{l}\text { CUPRAC } \\
\text { TEAC }^{* *}\end{array}$} \\
\hline & $\mathrm{IC}_{50}(\mathrm{mg} / \mathrm{mL}) *$ & $\mathrm{IC}_{50}(\mathrm{mM})$ & \\
\hline 2-Phenylethanol (1) & $265 \pm 3.2^{\mathrm{H} * * *}$ & $2172 \pm 30^{\mathrm{H}}$ & $0.023 \pm 0.002^{\mathrm{E}}$ \\
\hline Phenethyl acetate (8) & $119 \pm 4.2^{\mathrm{D}}$ & $726.2 \pm 19^{\mathrm{D}}$ & $0.021 \pm 0.002^{\mathrm{E}}$ \\
\hline Tyrosol (2) & $15.7 \pm 0.3^{\mathrm{A}}$ & $114.0 \pm 1.8^{\mathrm{A}}$ & $0.578 \pm 0.003^{\mathrm{B}}$ \\
\hline Tyrosyl acetate (9) & $20.4 \pm 0.5^{\mathrm{A}}$ & $113.0 \pm 2.8^{\mathrm{A}}$ & $0.456 \pm 0.005^{C}$ \\
\hline 3-Phenyl-1-propanol (3) & $389 \pm 11^{\mathrm{J}}$ & $2858 \pm 82 \mathrm{~J}$ & $0.021 \pm 0.003^{\mathrm{E}}$ \\
\hline 3-Phenyl-1-propyl acetate (10) & $235 \pm 1.5^{\mathrm{G}}$ & $1324 \pm 6.4^{\mathrm{G}}$ & $0.020 \pm 0.003^{\mathrm{E}}$ \\
\hline Phenylacetic acid (4) & $325 \pm 1.9^{\mathrm{I}}$ & $2396 \pm 12^{\mathrm{I}}$ & $0.020 \pm 0.003^{\mathrm{E}}$ \\
\hline Ethyl phenylacetate (11) & $185 \pm 5.5^{\mathrm{F}}$ & $1126 \pm 33^{\mathrm{F}}$ & $0.019 \pm 0.002^{\mathrm{E}}$ \\
\hline 4-Hydroxyphenylacetic acid (5) & $39.4 \pm 1.2^{\mathrm{BC}}$ & $258.9 \pm 7.8^{C}$ & $0.638 \pm 0.005^{\mathrm{A}}$ \\
\hline Ethyl 4-hydroxyphenylacetate (12) & $44.5 \pm 2.7^{C}$ & $247.2 \pm 15^{\mathrm{BC}}$ & $0.248 \pm 0.003^{\mathrm{D}}$ \\
\hline 3-Phenylpropanoic acid (6) & $161 \pm 8.2^{\mathrm{E}}$ & $1075 \pm 55^{\mathrm{F}}$ & $0.020 \pm 0.001^{\mathrm{E}}$ \\
\hline Ethyl 3-phenylpropanoate (13) & $157 \pm 9.0^{\mathrm{E}}$ & $879.5 \pm 50^{\mathrm{E}}$ & $0.031 \pm 0.001^{\mathrm{E}}$ \\
\hline 3-(4-hydroxyphenyl)propanoic acid (7) & $22.5 \pm 0.7^{\mathrm{AB}}$ & $135.7 \pm 4.1 \mathrm{AB}$ & $0.640 \pm 0.008^{\mathrm{A}}$ \\
\hline Ethyl 3-(4-hydroxyphenyl)propanoate (14) & $25.1 \pm 0.5^{\mathrm{AB}}$ & $129.3 \pm 2.5^{\mathrm{AB}}$ & $0.457 \pm 0.015^{\mathrm{C}}$ \\
\hline
\end{tabular}

* Concentration required for $50 \%$ reduction of the DPPH• radicals. ${ }^{* *}$ Trolox Equivalent Antioxidant Capacity.

*** The values with the same letter in a column did not differ significantly $(\alpha<0.05)$. 
For the first method, the lowest values, determining the best antioxidant properties, were obtained for tyrosol and its ester-tyrosyl acetate—and these values were $15.7 \mathrm{mg} / \mathrm{mL}(114 \mathrm{mM})$ and $20.4 \mathrm{mg} / \mathrm{mL}$ $(113 \mathrm{mM})$, respectively. The antioxidant activity of chemical compounds is associated with the presence of a hydroxyl group attached to an aromatic ring. Thus, the rest of compounds with hydroxyl group at the aromatic ring also demonstrated antioxidant activity with values not exceeding $45 \mathrm{mg} / \mathrm{mL}$ $(260 \mathrm{mM})$. Compounds not containing a hydroxyl group attached to an aromatic ring showed moderate or weak antioxidant activity. $\mathrm{IC}_{50}$ values were from 5 to even 25 times higher than those obtained for tyrosol and its ester. Expressing the $\mathrm{IC}_{50}$ value by the molar concentration is more accurate, because it takes into account the molar mass of the compound, which in the case of lipophilic esters can be relatively higher for the ester than for the initial substrate. Thus, comparing $\mathrm{IC}_{50}$ values in $\mathrm{mM}$ the same number of molecules is being compared. Accordingly, it can be concluded that obtained esters have very similar antioxidant properties to their precursors.

Although the DPPH• radical method and the CUPRAC method are methods based on the SET mechanism (single electron transfer) [42], the results obtained for the second one were slightly different. In the CUPRAC method, the antioxidant's ability to reduce $\mathrm{Cu}$ (II) ions is determined, and the reaction took place in a water-ethanol environment, unlike the DPPH• method, where an environment consisting entirely of an organic substance-methanol. The best TEAC values were obtained for the following compounds: 3-(4-hydroxyphenyl)propanoic acid $(0.640 \pm 0.008)$, 4-hydroxyphenylacetic acid $(0.638 \pm 0.005)$, and tyrosol $(0.578 \pm 0.003)$. Lower values were obtained for the esters of the aforementioned compounds: ethyl 3-(4-hydroxyphenyl)propanoate $(0.457 \pm 0.015)$, tyrosyl acetate $(0.456 \pm 0.005)$, and ethyl 4-hydroxyphenylacetate $(0.248 \pm 0.003)$. Other compounds showed no activity in this method.

A larger number of hydroxyl groups, their position, and additionally the presence of methoxy groups increases the described properties [21]. According to the studies by Reis et al. [43], lipophilicity, apart from the presence of hydroxyl groups, is an important factor influencing the antioxidant properties of chemical compounds. Both cLogP and cLogS values in Table 2 indicated that esters obtained should dissolve better in the lipid phase than in the aqueous phase, which points at their possible use in lipid-rich food matrices.

According to the correlation matrix (Table 6), the relationship between the values obtained in both assays can be seen. There is a significant correlation between the antioxidant activity methods used. In addition, there is a correlation in both cases between the method used and the number of hydrogen acceptors, electronegative atoms, and TPSA. These values are closely related-electronegative atoms are hydrogen acceptors, and TPSA is linked to the sum of the surfaces of all polar atoms. In addition, the CUPRAC method was correlated with $\operatorname{cLog} P, \operatorname{cog} S$, and the number of hydrogen donors, which are also partly related. Non-esterified compounds, and thus containing more hydrogen donors and being less soluble in nonpolar solvents, had higher TEAC values. As for the DPPH• method, this method had a significant correlation with molecular weight and number of non-hydrogen atoms. Esterified compounds had higher molecular weight, thus also had more atoms other than hydrogen. Negative correlation indicates that the higher values of the aforementioned parameters affect the lowering of the $\mathrm{IC}_{50}$ value, and the lower the value, the greater the antioxidant activity. According to the correlation matrix, it can be also seen that parameters such as a number of $\mathrm{sp}^{3}$ atoms and total surface area did not have any significant impact on the antioxidant properties of tested compounds. 
Table 6. Correlation matrix between antioxidant activity and calculated properties of tested compounds.

\begin{tabular}{|c|c|c|c|c|c|c|c|c|c|c|c|c|}
\hline & $\begin{array}{l}\text { Molecular } \\
\text { Weight }\end{array}$ & $\operatorname{cLog} P$ & cLogS & H-Acceptors & H-Donors & $\begin{array}{l}\text { Non-H } \\
\text { Atoms }\end{array}$ & $\begin{array}{l}\text { Electronegative } \\
\text { Atoms }\end{array}$ & $\mathrm{sp}^{3}$-Atoms & $\begin{array}{c}\text { Total } \\
\text { Surface } \\
\text { Area }\end{array}$ & $\begin{array}{c}\text { Topological } \\
\text { Polar Surface } \\
\text { Area }\end{array}$ & $\begin{array}{l}\text { CUPRAC } \\
\text { (TEAC) }\end{array}$ & $\begin{array}{c}\text { DPPH } \\
\left(\text { ic }_{50}\right)\end{array}$ \\
\hline $\begin{array}{l}\text { CUPRAC } \\
\text { (TEAC) }\end{array}$ & 0.207 & $\underset{*}{-0.571}$ & 0.641 * & 0.714 * & $0.796^{*}$ & 0.165 & $0.714^{*}$ & 0.196 & -0.031 & $0.867^{*}$ & 1.000 & -0.733 * \\
\hline $\begin{array}{c}\mathrm{DPPH} \bullet \\
\left(\mathrm{IC}_{50}\right)\end{array}$ & -0.632 * & 0.144 & -0.178 & $-0.837^{*}$ & -0.293 & $-0.605^{*}$ & $-0.837^{*}$ & -0.499 & -0.450 & $-0.717^{*}$ & $-0.733 *$ & 1.000 \\
\hline
\end{tabular}

* Significant at $\alpha<0.05$. 


\subsection{Evaluation of Antimicrobial Activity of Obtained Esters and Their Precursors}

Among the biological activities studied, antimicrobial activity is one of the most important in the context of using new substances as food additives. Table 7 shows the minimum inhibitory concentrations (MIC) and minimum microbicidal concentrations (MMC, in brackets) values of the compounds tested. Synthesized esters such as phenethyl acetate, 3-phenyl-1-propyl acetate, ethyl phenylacetate, and ethyl 3-phenylpropanoate turned out to be weak antimicrobial agents. On the other hand, their precursors, especially 3-phenyl-1-propanol and phenylacetic acid, proved to have the highest antimicrobial activity (3P1P and PA had the lowest MIC values). Other precursors of the aforementioned esters, i.e., 3-phenylpropanoic acid and 2-phenylethanol, also exhibited better inhibitory effect towards microorganisms than their ethyl or acetate esters. Antimicrobial activity of 2-phenylethanol, 2-phenylacetaldehyde, and phenylacetic acid was also investigated by Zhu et al. [44]. Similar to the current work, Zhu et al. [44] showed that phenylacetic acid was more effective than 2-phenylethanol, and 2-phenylacetaldehyde did not have any activity.

In the case of esters with a hydroxyl group, i.e., ethyl 4-hydroxyphenylacetate and ethyl 3-(4-hydroxyphenyl)propanoate, it can be observed that their activity is similar to their precursors, but it is not confirmed for tyrosyl and its ester, where tyrosyl acetate was much more active. Gram negative bacteria were more susceptible to tested compounds compared to gram positive bacteria. MIC values obtained in yeast testing were the least varied between species. Among the microorganisms tested, K. pneumoniae and C. freundii were most sensitive to the action of synthesized esters and their precursors, and on the other side, E. faecalis and bacteria from Bacillus genus proved to be the most resistant. In this first group, concentration of $2.5 \mathrm{mg} / \mathrm{mL}$, in most cases, was sufficient to inhibit their growth. It is possible that esters with a hydroxyl group compared to their analogs not containing a hydroxyl group could more easily get through the outer membrane and thin cell wall of Gram-negative bacteria, causing their growth inhibition. Gram-positive bacteria with thicker cell wall remained resistant to the action of the tested esters. Minimum microbicidal concentration for B. cereus PCM 482 was in all cases at least $10 \mathrm{mg} / \mathrm{mL}$, which means that it was not possible to determine the concentration required to kill this strain in the concentration range used. Obtained results indicate that this strain was the most resistant to the tested compounds among all microorganisms.

Sanchez-Maldonado et al. [45] determined MIC values of six hydroxybenzoic and six hydroxycinnamic acids for Lactobacillus plantarum, L. hammesii, E. coli, and B. subtilis. According to their results, antibacterial activity was enhanced with decreasing number of hydroxyl groups with major effects on hydroxybenzoic acids rather than hydroxycinnamic acids, and substitution of hydroxyl groups with methoxy groups increased the activity only of hydroxybenzoic acids. The mechanism of antimicrobial action of phenolic acids and their esters has not been well understood yet, but studies are in progress on membrane permeability or inhibition of key enzymes that affect the growth and multiplication of microorganism cells [46]. 
Table 7. Minimum inhibitory concentrations (MIC) (mg/mL) and minimum microbicidal concentrations in brackets (MMC) (mg/mL) of tested compounds.

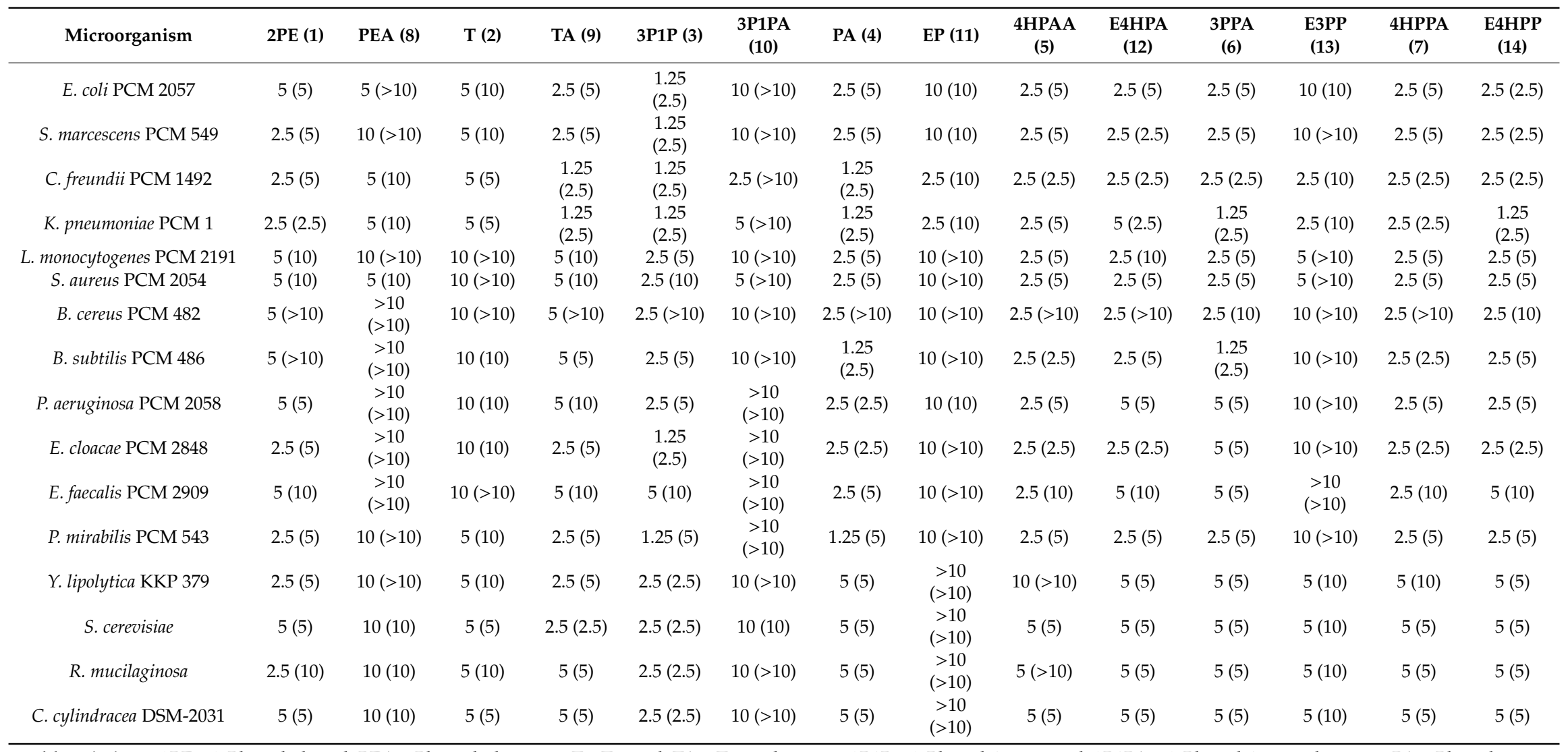

Abbreviations: 2PE—-Phenylethanol; PEA—Phenethyl acetate; T-Tyrosol, TA—Tyrosyl acetate; 3P1P—3-Phenyl-1-propanol; 3P1PA—3-Phenyl-1-propyl acetate; PA—Phenylacetic acid; EP-Ethyl phenylacetate; 4HPAA—4-Hydroxyphenylacetic acid; E4HPA—Ethyl 4-hydroxyphenylacetate; 3PPA-3-Phenylpropanoic acid; E3PP-Ethyl 3-phenylpropanoate; 4HPPA-3-(4-hydroxyphenyl)propanoic acid; E4HPP-Ethyl 3-(4-hydroxyphenyl)propanoate. 
For complex evaluation of obtained data, cluster analysis was applied. Cluster analysis is a statistical technique of grouping observations into similar groups (called clusters). Objects in the same group are more similar to those from the other groups [47]. Cluster analysis summarized all the differences between the tested compounds and the results were presented in Figure 4.

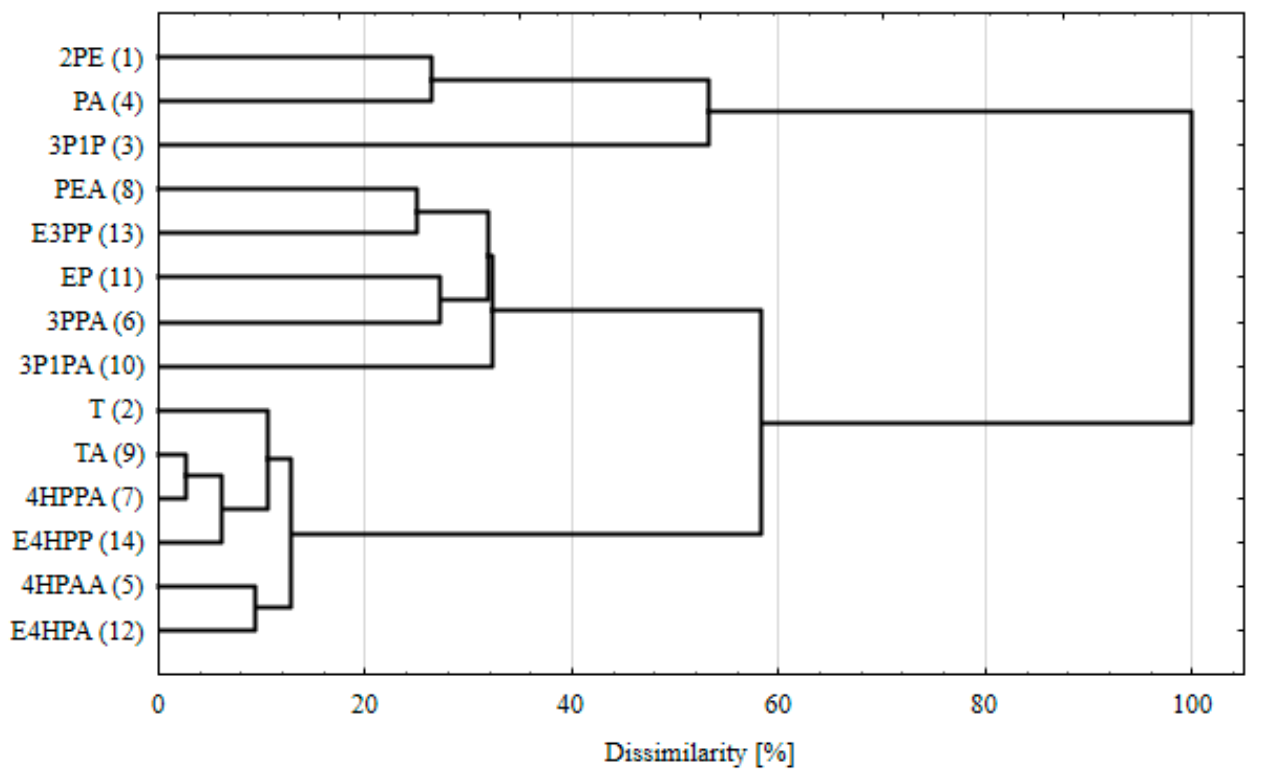

Figure 4. The results of cluster analysis. Abbreviations: 2PE-2-Phenylethanol; PEA-Phenethyl acetate; T-Tyrosol, TA-Tyrosyl acetate; 3P1P-3-Phenyl-1-propanol; 3P1PA-3-Phenyl-1-propyl acetate; PA-Phenylacetic acid; EP-Ethyl phenylacetate; 4HPAA — 4-Hydroxyphenylacetic acid; E4HPA-Ethyl 4-hydroxyphenylacetate; 3PPA-3-Phenylpropanoic acid; E3PP-Ethyl 3-phenylpropanoate; 4HPPA-3-(4-hydroxyphenyl)propanoic acid; E4HPP-Ethyl 3-(4-hydroxyphenyl)propanoate.

According to the data obtained in the current study, which included the study of antioxidant activity by CUPRAC and DPPH• methods and determination of MIC values of esters and their precursors by the microdilution broth method, the following three clusters could be distinguished: (1) non-esterified compounds exhibiting antimicrobial activity with very poor antioxidant properties, i.e., 2-phenylethanol, phenylacetic acid, and 3-phenyl-1-propanol; (2) a group of five compounds, mainly esters with better antioxidant activity than the first group; (3) a cluster including compounds with hydroxyl group attached to an aromatic ring responsible for high antioxidant activity. Analyzing Figure 4, it can be also seen that compounds in the last described cluster are the closest to each other, which results from the smallest percentage dissimilarity.

This is probably the first attempt, not described in the scientific literature earlier, of using waste fish oil in obtaining biomass with lipolytic properties capable of catalyzing esterification and transesterification of phenolic compounds. Utilization of waste substrates in the microbiological production of valuable metabolites contributes to reducing their costs, and in the case of enzymes, their use in the industry helps to reduce the consumption of chemical catalysts. On the other hand, not all reactions proceeded at the satisfactory level due to the specificity of the biocatalyst used, which should be more versatile. Despite that whole-cell biocatalysts can catalyze many reactions without complicated and expensive enzyme purification processes, they are often susceptible to inhibition caused by substrates, products, or solvent of the reaction. Although the results are promising, further research should be carried out to optimize the action of catalysts in the synthesis of phenolic compounds esters. 


\section{Conclusions}

Principles of green and sustainable chemistry established some basic standards for all new chemical synthesis processes, which involve minimization of energy costs, using recyclable and selective catalysts, waste utilization alongside with its valorization, etc. To summarize, it was proven that a waste fish oil could be a very good substrate for the production of $Y$. lipolytica yeast biomass with catalytic properties. Among the four tested strains of Y. lipolytica, two of them were able to grow and produce lipolytic enzymes at a satisfactory level in medium with waste fish oil, which allowed for developing biocatalysts useful in new molecules synthesis. Enzymes present in Y. lipolytica biomass were able to catalyze the esterification of 3-phenylpropanoic acid with high conversion. Parameters such as number of hydrogen acceptors, electronegative atoms, and TPSA correlated with antioxidant properties of tested compounds, and it was acknowledged that the hydroxyl group attached to an aromatic ring was responsible for antioxidant activity of phenolic acids derivatives. In addition, esters of hydroxylated phenolic compounds in comparison with their precursors were characterized by better solubility in lipids, which increased the possibility of their use in the food industry. For the biotechnologists and chemists, a new way of possessing useful chemicals along with developing new molecules is what matters and what was underlined in the present paper.

Supplementary Materials: The following are available online at http://www.mdpi.com/2071-1050/12/14/5804/s1, Raw NMR data (e.g., fid files) of the synthesized compounds.

Author Contributions: Conceptualization, B.Z., A.F., and E.B.-F.; methodology, B.Z. and A.F.; formal analysis, B.Z.; investigation, B.Z. and M.W.; writing—original draft preparation, B.Z.; writing-review and editing, B.Z., A.F., and E.B.-F.; visualization, B.Z.; supervision, E.B.-F. and A.F.; funding acquisition, B.Z. All authors have read and agreed to the published version of the manuscript.

Funding: This work was financially supported by Institute of Food Sciences, Warsaw University of Life Sciences (Grant No. 505-10-092700-Q00345-99).

Conflicts of Interest: The authors declare no conflict of interest.

\section{References}

1. Usydus, Z.; Szlinder-Richter, J. Functional properties of fish and fish products: A review. Int. J. Food Prop. 2012, 15, 823-846. [CrossRef]

2. Zieniuk, B.; Fabiszewska, A. Ryby oraz odpady rybne jako źródło składników bioaktywnych oraz surowiec dla przemysłu energetycznego. Żywność Nauka Technologia Jakość 2018, 25, 5-16.

3. Kraiem, T.; Hassen-Trabelsi, A.B.; Naoui, S.; Belayouni, H.; Jeguirim, M. Characterization of the liquid products obtained from Tunisian waste fish fats using the pyrolysis process. Fuel Process. Technol. 2015, 138, 404-412. [CrossRef]

4. Rustad, T.; Storrø, I.; Slizyte, R. Possibilities for the utilisation of marine by-products. Int. J. Food Sci. Tech. 2011, 46, 2001-2014. [CrossRef]

5. Kristinsson, H.G.; Rasco, B.A. Fish protein hydrolysates: Production, biochemical, and functional properties. Crit. Rev. Food Sci. Nutr. 2000, 40, 43-81. [CrossRef]

6. Jayathilakan, K.; Sultana, K.; Radhakrishna, K.; Bawa, A.S.L. Utilization of byproducts and waste materials from meat, poultry and fish processing industries: A review. J. Food Sci. Technol. 2012, 49, 278-293. [CrossRef]

7. Bücker, F.; Marder, M.; Peiter, M.R.; Lehn, D.N.; Esquedro, V.M.; de Almeida Pinto, L.A.; Konrad, O. Fish waste: An efficient alternative to biogas and methane production in an anaerobic mono-digestion system. Renew. Energy 2020, 147, 798-805. [CrossRef]

8. Yahyaee, R.; Ghobadian, B.; Najafi, G. Waste fish oil biodiesel as a source of renewable fuel in Iran. Renew. Sustain. Energy Rev. 2013, 17, 312-319. [CrossRef]

9. Tchobanoglous, G.; Burton, F.; Stensel, H.D. Wastewater Engineering: Treatment and Reuse, 4th ed.; Metcalf \& Eddy, International Edition: Boston, MA, USA, 2003.

10. Yano, Y.; Oikawa, H.; Satomi, M. Reduction of lipids in fish meal prepared from fish waste by a yeast Yarrowia lipolytica. Int. J. Food Microbiol. 2008, 121, 302-307. [CrossRef] 
11. Aarthy, M.; Saravanan, P.; Ayyadurai, N.; Gowthaman, M.K.; Kamini, N.R. A two-step process for production of omega 3-polyunsaturated fatty acid concentrates from sardine oil using Cryptococcus sp. MTCC 5455 lipase. J. Mol. Catal. B Enzym. 2016, 125, 25-33. [CrossRef]

12. Shinmen, Y.; Kawashima, H.; Shimizu, S.; Yamada, H. Concentration of eicosapentaenoic acid and docosahexaenoic acid in an arachidonic acid-producing fungus, Mortierella alpina 1S-4, grown with fish oil. Appl. Microbiol. Biotechnol. 1992, 38, 301-304. [CrossRef]

13. Aoki, H.; Miyamoto, N.; Furuya, Y.; Mankura, M.; Endo, Y.; Fujimoto, K. Incorporation and accumulation of docosahexaenoic acid from the medium by Pichia methanolica HA-32. Biosci. Biotechnol. Biochem. 2002, 66, 2632-2638. [CrossRef]

14. Kinoshita, H.; Ota, Y. Concentration of docosahexaenoic acid from fish oils using Geotrichum sp. FO347-2. Biosci. Biotechnol. Biochem. 2001, 65, 1022-1026. [CrossRef]

15. Katre, G.; Joshi, C.; Khot, M.; Zinjarde, S.; RaviKumar, A. Evaluation of single cell oil (SCO) from a tropical marine yeast Yarrowia lipolytica NCIM 3589 as a potential feedstock for biodiesel. AMB Express 2012, 2, 36. [CrossRef] [PubMed]

16. Mazurczak, P.; Zieniuk, B.; Fabiszewska, A.; Nowak, D.; Wołoszynowska, M.; Białecka-Florjańczyk, E. Utylizacja odpadów pochodzących z zakładów przemysłu spożywczego i paliwowego z wykorzystaniem lipolitycznych drożdży Yarrowia lipolytica. Zeszyty Problemowe Postępów Nauk Rolniczych 2017, 588, 15-24. [CrossRef]

17. Zieniuk, B.; Fabiszewska, A. Yarrowia lipolytica: A beneficious yeast in biotechnology as a rare opportunistic fungal pathogen: A minireview. World J. Microbiol. Biotechnol. 2019, 35, 10. [CrossRef] [PubMed]

18. Fickers, P.; Marty, A.; Nicaud, J.M. The lipases from Yarrowia lipolytica: Genetics, production, regulation, biochemical characterization and biotechnological applications. Biotechnol. Adv. 2011, 29, 632-644. [CrossRef]

19. Sharma, S.; Kanwar, S.S. Organic solvent tolerant lipases and applications. Sci. World J. 2014, $2014,625258$. [CrossRef] [PubMed]

20. Zieniuk, B.; Wołoszynowska, M.; Białecka-Florjańczyk, E. Enzymatic synthesis of biodiesel by direct transesterification of rapeseed cake. Int. J. Food Eng. 2020, 16, 3. [CrossRef]

21. Białecka-Florjańczyk, E.; Fabiszewska, A.; Zieniuk, B. Phenolic acids derivatives-biotechnological methods of synthesis and bioactivity. Curr. Pharma. Biotechnol. 2018, 19, 1098-1113. [CrossRef]

22. Ozcan, T.; Akpinar-Bayizit, A.; Yilmaz-Ersan, L.; Delikanli, B. Phenolics in human health. Int. J. Chem. Eng. Appl. 2014, 5, 393-396. [CrossRef]

23. Saibabu, V.; Fatima, Z.; Khan, L.A.; Hameed, S. Therapeutic potential of dietary phenolic acids. Adv. Pharmacol. Sci. 2015, 2015, 1-10. [CrossRef] [PubMed]

24. Guzman, J.D. Natural cinnamic acids, synthetic derivatives and hybrids with antimicrobial activity. Molecules 2014, 19, 19292-19349. [CrossRef] [PubMed]

25. Roby, M.H.H. Synthesis and Characterization of Phenolic Lipids. In Phenolic Compounds-Natural Sources, Importance and Applications; Soto-Hernandez, M., Palma-Tenango, M., del Rosario Garcia-Mateos, M., Eds.; IntechOpen: London, UK, 2017; pp. 89-116.

26. Figueroa-Espinoza, M.C.; Villeneuve, P. Phenolic Acids Enzymatic Lipophilization. J. Agric. Food Chem. 2005, 53, 2779-2787. [CrossRef]

27. Zieniuk, B.; Fabiszewska, A.; Białecka-Florjańczyk, E. Screening of solvents for favoring hydrolytic activity of Candida antarctica Lipase B. Bioproc. Biosyst. Eng. 2020, 43, 605-613. [CrossRef]

28. Kapturowska, A.; Stolarzewicz, I.; Krzyczkowska, J.; Białecka-Florjańczyk, E. Studies on lipolytic activity of sonicated enzymes from Yarrowia lipolytica. Ultrason. Sonochem 2012, 19, 186-191. [CrossRef]

29. Zanetti, M.; Carniel, T.K.; Valerio, A.; de Oliveira, J.V.; de Oliveira, D.; de Araujo, P.H.H.; Riella, H.G.; Fiori, M.A. Synthesis of geranyl cinnamate by lipase-catalyzed reaction and its evaluation as an antimicrobial agent. J. Chem. Technol. Biotechnol. 2017, 92, 115-121. [CrossRef]

30. Özyürek, M.; Güçlü, K.; Apak, R. The main and modified CUPRAC methods of antioxidant measurement. TrAC Trend. Anal. Chem. 2011, 30, 652-664. [CrossRef]

31. International Organization for Standards. ISO 20776-1. Clinical laboratory Testing and In Vitro Diagnostic Test Systems-Susceptibility Testing of Infectious Agents and Evaluation of Performance of Antimicrobial Susceptibility Test Devices-Part 1: Reference Method for Testing the In Vitro Activity of Antimicrobial Agents against Rapidly Growing Aerobic Bacteria Involved in Infectious Diseases; International Organization for Standards: Geneva, Switzerland, 2006. 
32. Arendrup, M.C.; Meletiadis, J.; Mouton, J.W.; Lagrou, K.; Hamal, P.; Guinea, J.; Subcommittee on Antifungal Susceptibility Testing (AFST) of the ESCMID European Committee for Antimicrobial Susceptibility Testing (EUCAST). EUCAST DEFINITIVE DOCUMENT E.DEF 7.3.1 Method for the Determination of Broth Dilution Minimum Inhibitory Concentrations of Antifungal Agents for Yeasts. Available online: http://www.eucast.org/fileadmin/src/media/PDFs/EUCAST_files/AFST/Files/EUCAST_E_Def_7_ 3_1_Yeast_testing_definitive.pdf(2017) (accessed on 28 June 2020).

33. Fabiszewska, A.; Stolarzewicz, I.; Zamojska, W.; Białecka-Florjańczyk, E. Carbon source impact on Yarrowia lipolytica KKP 379 lipase production. Appl. Biochem. Microbiol. 2014, 50, 404-410. [CrossRef]

34. Akpinar, O.; Ucar, F.B. Molecular characterization of Yarrowia lipolytica strains isolated from different environments and lipase profiling. Turk. J. Biol. 2013, 37, 249-258.

35. Lopes, M.; Gomes, N.; Mota, M.; Belo, I. Yarrowia lipolytica growth under in-creased air pressure: Influence of enzyme production. Appl. Biochem. Biotechnol. 2009, 159, 46-53. [CrossRef] [PubMed]

36. Wang, Y.; Zhang, D.H.; Chen, N.; Zhi, G.Y. Synthesis of benzyl cinnamate by enzymatic esterification of cinnamic acid. Bioresour. Technol. 2015, 198, 256-261. [CrossRef] [PubMed]

37. Jakovetić, S.M.; Jugović, B.Z.; Gvozdenović, M.M.; Bezbradica, D.I.; Antov, M.G.; Mijin, D.Z.; Knežević-Jugović, Z.D. Synthesis of aliphatic esters of cinnamic acid as potential lipophilic antioxidants catalyzed by lipase B from Candida antarctica. Appl. Biochem. Biotechnol. 2013, 170, 1560-1573. [CrossRef] [PubMed]

38. Weber, H.K.; Stecher, H.; Faber, K. Sensitivity of microbial lipases to acetaldehyde formed by acyl-transfer reactions from vinyl esters. Biotechnol. Lett. 1995, 17, 803-808. [CrossRef]

39. Weber, H.K.; Zuegg, J.; Faber, K.; Pleiss, J. Molecular reasons for lipase-sensitivity against acetaldehyde. J. Mol. Catal. B Enzym. 1997, 3, 131-138. [CrossRef]

40. Weber, H.K.; Faber, K. Stabilization of lipases against deactivation by acetaldehyde formed in acyl transfer reactions. Method Enzymol. 1997, 286, 509-518.

41. Guyot, B.; Bosqette, B.; Pina, M.; Graille, J. Esterification of phenolic acids from green coffee with an immobilized lipase from Candida antarctica in solvent-free medium. Biotechnol. Lett. 1997, 19, 529-532. [CrossRef]

42. Apak, R.; Gorinstein, S.; Bohm, V.; Schaich, K.M.; Ozyurek, M.; Guclu, K. Methods of measurement and evaluation of natural antioxidant capacity/activity (IUPAC Technical Report). Pure Appl. Chem. 2013, 85, 957-998. [CrossRef]

43. Reis, B.; Martins, M.; Barreto, B.; Milhazes, N.; Garrido, E.M.; Silva, P.; Garrido, J.; Borges, F. Structure-property-activity relationship of phenolic acids and derivatives. protocatechuic acid alkyl esters. J. Agric. Food Chem. 2010, 58, 6986-6993. [CrossRef]

44. Zhu, Y.J.; Zhou, H.T.; Hu, Y.H.; Tang, J.Y.; Su, M.X.; Guo, Y.J.; Chen, Q.X.; Liu, B. Antityrosinase and antimicrobial activities of 2-phenylethanol,2-phenylacetaldehyde and 2-phenylacetic acid. Food Chem. 2011, 124, 298-302. [CrossRef]

45. Sanchez-Maldonado, A.F.; Schieber, A.; Ganzle, M.G. Structure-function relationships of the antibacterial activity of phenolic acids and their metabolism by lactic acid bacteria. J. Appl. Microbiol. 2011, 111, 1176-1184. [CrossRef] [PubMed]

46. Rempe, C.S.; Burris, K.P.; Lenaghan, S.C.; Stewart, C.N. The potential of systems biology to discover antibacterial mechanisms of plant phenolics. Front. Microbiol. 2017, 8, 422. [CrossRef] [PubMed]

47. Ketchen, D.J.; Shook, C.L. The application of cluster analysis in strategic management research: An analysis and critique. Strateg. Manag. 1996, 17, 441-458. [CrossRef]

(C) 2020 by the authors. Licensee MDPI, Basel, Switzerland. This article is an open access article distributed under the terms and conditions of the Creative Commons Attribution (CC BY) license (http://creativecommons.org/licenses/by/4.0/). 